\title{
Effect of Some Biopreparations on Health Status of Strawberry (Fragaria ananassa Duch.)
}

\author{
Anna Wagner and Beata Hetman \\ Department of Plant Protection and Quarantine, University of Life Sciences, 20-069 Lublin, Poland
}

\begin{abstract}
The study aimed at comparing the effect of selected biopreparations (Boni protect forte, beta-chikol, Trianum P) and fungicide treatment Switch 62.5 WG (cyprodinil + fludioxonil) on the health status of strawberry grown in the fruiting field at the strawberry farm in Jasionka, Lublin region. The experiment was conducted for three years (2012-2014). Results showed that the application of all biopreparations and fungicide significantly reduced the number of diseased plants and the disease index. The effect of three biological products was similar. The mycological analysis of plants showed that among the fungi potentially pathogenic to strawberry, Fusarium spp., Cylindrocarpon spp., Botrytis cinerea and Alternaria were predominated. The fewest colonies of pathogenic fungi were isolated from plants treated with Trianum P.
\end{abstract}

Key words: Strawberry, biological control, fungicide, populations of fungi.

\section{Introduction}

Strawberry is the most important fruit crop in Poland after apple. Big quantities of fresh and frozen fruit as well as rootstocks are exported to many countries. The yield of strawberry depends on many factors, and among them, the most important one is its health status. In Poland, the most important pathogens of strawberry are Fusarium spp, Botrytis cinerea, Colletotrichum acutatum, and in some years Cylindrocarpon spp. and Alternaria alternata [1, 2]. They can infect all above- and under-ground organs causing necrosis and wilting of plants. The chemical control of diseases is still widely used owing to its efficacy and the simplicity of application. However, many pathogens become resistant to some fungicides and the application of chemicals has a negative effect on the environment [3]. As consumers pay more attention to pesticides residues in fruits, there is the need of using alternative methods in horticultural farms. One of these methods is the use of biological preparations based on natural substances and antagonistic organisms [4-6].

Corresponding author: Anna Wagner, professor, research fields: phytopathology and plant protection.
Among the effective antagonists in biological control of plant pathogens, the most known are Trichoderma spp. [7, 8]. Recently, the biopreparation Trianum P, containing Trichoderma harzianum T22 has been registered in Poland for plant protection. Apart from well known fungal antagonists, such as Trichoderma, Pythium or Gliocladium, the yeasts species were tested in many countries for their efficacy in plant protection. Some Polish researchers showed the effectiveness of yeast strains in the control of postharvest diseases of fruits and vegetables [9]. The yeasts antagonism is based mostly on the competition for nutrients. Similar activity is characteristic for yeast-like fungus, Aureobasidium pullulans [10], which already is used in commercial products.

The bioproducts based on natural substances are used in plant protection for decades. There are the preparations with grapefruit extract [11], garlic pulp [12] and chitosan [13]. All of the biological preparations can control the pathogens directly or induce the defense reactions of plant $[8,14,15]$.

This study aimed to compare the health status of strawberry plants treated with the biopreparations and 
the fungicide to the health status of untreated plants.

\section{Materials and Methods}

\subsection{Experienment Design}

The objects of the study were the strawberry plants cv. "Elsanta" grown in the field at the strawberry farm in Jasionka, Lublin region. For plant protection, three bioproducts, ie., Trianum $\mathrm{P}$-Trichoderma harzianum T22 (Koppert Polska sp. z o.o., Poland), beta-chikol—chitosan (Poli-Farm sp. z o.o.) and Boni protect forte-Aureobasidium pullulans (Koppert Polska sp. z o.o.) were applied five times during vegetation periods (2012-2014). Trianum P $(0.4 \%)$ was applied at the dose of $3 \mathrm{~g} / \mathrm{m}^{2}$, beta-chikol (2\%) at $15 \mathrm{~mL} / \mathrm{m}^{2}$ and Boni protect forte $(0.1 \%)$ at $0.3 \mathrm{~g} / \mathrm{m}^{2}$. For the comparison, there were two other combinations: control (without any treatment) and fungicide treatment (Switch 62.5 WG 0.1\%, two applications a year at the dose of $0.75 \mathrm{~g} / \mathrm{m}^{2}$ ). The experiment was carried out in randomized blocks with four replications for each combination and 20 plants for the replication.

\subsection{Evaluation of Plants Health Status and Disease Severity}

For each combination, the percentage of diseased plants was counted in the field. To estimate the disease intensity, the 5-degree scale was used, where 0 represents no disease symptoms, 1 represents few small necrotic spots on leaves and petioles, 2 represents numerous necrotic spots on tested organs, 3 represents necrotic lesions on more than half of organs surface and 4 represents wilting and decaying of plants. The data were processed by McKinney's formula [16], which generates a numeric disease index (DI) of the severity of the attack, as Eq. (1):

$$
\mathrm{DI}=(\Sigma v n / N V) \times 100
$$

where, $v$ represents the numeric value of the degree, $n$ is the number of plants assigned to the degree, $N$ is the total number of plants in the replication and $V$ is the numeric value of the highest degree.
The results were evaluated statistically with the analysis of variance (ANOVA) and the differences between means were estimated by Tukey's test $(P<$ 0.05) using Statistica 12.0.

\subsection{Mycological Analysis of Plants}

Each year, in the first decade of September, the plants with disease symptoms were collected for mycological analysis in the laboratory. The leaves, crowns and roots were analyzed separately. The organs were rinsed in tap water and sterilized in 50\% ethanol for $1 \mathrm{~min}$ and in $0.1 \%$ sodium hypochlorite for $1 \mathrm{~min}$. The $3 \mathrm{~mm}$ fragments (200 per combination) were placed on the mineral medium (sucrose- $38 \mathrm{~g}$; $\mathrm{NH}_{4} \mathrm{NO}_{3}-0.7 \mathrm{~g} ; \mathrm{KH}_{2} \mathrm{PO}_{4}-0.3 \mathrm{~g} ; \mathrm{MgSO}_{4} \cdot 7 \mathrm{H}_{2} \mathrm{O}-0.3 \mathrm{~g}$; trace of $\mathrm{FeCl}_{3} \cdot 6 \mathrm{H}_{2} \mathrm{O}, \mathrm{ZnSO}_{4} \cdot 7 \mathrm{H}_{2} \mathrm{O}, \mathrm{CuSO}_{4} \cdot 7 \mathrm{H}_{2} \mathrm{O}$ and $\mathrm{MnSO}_{4} \cdot 5 \mathrm{H}_{2} \mathrm{O}$; agar-20 g to fill up to $1,000 \mathrm{~mL}$ of distilled water) in Petri dishes that were stored in $20-22{ }^{\circ} \mathrm{C}$ for $7 \mathrm{~d}$. After that, the fungal colonies were transferred into PDA (Difco) slants, stored under the same conditions as Petri dishes for $10 \mathrm{~d}$. Later, the species of fungi were determined with the use of laboratory and electronic microscope.

\section{Results}

\subsection{Health Status and Disease Severity of Strawberry}

During the experiment, the diseased plants occurred the symptoms of necrosis, changes in coloring of leaves, decay of flower buds and wilting. The application of all bioproducts and the fungicide significantly reduced the number of diseased plants in the field. The highest mean percentage of diseased plants was noticed for the control combination $(27.66 \%)$ and the lowest one for the plants treated with the fungicide Switch 62.5 WG $(9.00 \%)$. The mean percentage of affected plants in the combinations with bioproducts was similar and far lower than that in the control combination (Table 1). Similarly, the mean disease index (DI) also was the highest in the control combination (17.16\%) and the lowest one in the combination with Switch $62.5 \mathrm{WG}$ 
$(8.33 \%)$. The mean values of disease index for the plants treated with the biopreparations were similar and lower than that in the control combination (Table 1).

\subsection{Results of Mycological Analysis}

As the result of mycological analysis, 1,335 fungal isolates were obtained from the leaves of strawberry. The main colonizer in 2013 and 2014 was Botrytis cinerea. Other potential pathogenic colonizers were Alternaria alternata, Rhizoctonia solani and Fusarium spp.. The lowest number of fungal colonies was isolated from the leaves treated with Switch 62.5 WG and Trianum $\mathrm{P}$, while the highest one from the plants in the control combination. The frequency of Botrytis cinerea was the lowest in the combination with the fungicide and with Boni protect forte, while Fusarium spp. were isolated most frequently from the plants grown in the control combination with F. avenaceum as a predominating species. Alternaria alternata occurred very often on the leaves of plants in all combinations in 2012, but not in 2013 and 2014 (Tables 2-4).

The mycological analysis of crowns and roots resulted in 2,130 isolates. Among isolated fungi, Fusarium spp. and Rhizoctonia solani predominated. The highest number of Fusarium spp. was obtained from the plants treated with beta-chikol and the lowest one in the combination with Trianum $\mathrm{P}$. Among these fungi, F. avenaceum and F. oxysporum predominated, thus, the species are potentially pathogenic to strawberry. In the combination with Trianum P, Cylindrocarpon spp. occurred frequently (Tables 2-4).

Among potential antagonistic fungi, Trichoderma harzianum predominated, but this fungus was isolated only from the plants treated with Trianum P. The colonies of other antagonists, such as Gliocladium fimbriatum and Penicillium purpurogenum, were less numerous, and their frequency was the highest in 2013 (Tables 2-4).

\section{Discussion}

In the production of fruits and vegetables, the biological preparations are used to control the pathogens and the pests, as well as to stimulate the growth and development of plants. These products are used mostly in organic and integrated horticulture [17-20]. The results of the present investigations showed that the tested preparations had an effect on the disease intensity and fugal populations in a various degree. The number of diseased plants and the disease index varied slightly depending on the preparation used, but all bioproducts reduced both the percentage of affected plants and the disease index.

The lowest mean disease index was noticed for beta-chikol containing chitosan. Chitosan, a high molecular weight polymer, is produced from the chitin components of arthropod exoskeleton [14]. Its role in the protection of many plants against pathogenic fungi was confirmed by other researchers [21-23]. Chitosan

Table 1 Percentage of infection and disease index of strawberry protected with biological preparations in 2012-2014.

\begin{tabular}{|c|c|c|c|c|c|c|c|c|}
\hline \multirow{3}{*}{$\begin{array}{l}\text { Experimental } \\
\text { combinations }\end{array}$} & \multicolumn{4}{|c|}{ Percentage of infected plants $(\%)$} & \multicolumn{4}{|c|}{ Disease index $(\%)$} \\
\hline & \multicolumn{3}{|c|}{ Year } & \multirow{2}{*}{-Mean } & \multicolumn{3}{|c|}{ Year } & \multirow{2}{*}{-Mean } \\
\hline & 2012 & 2013 & 2014 & & 2012 & 2013 & 2014 & \\
\hline $\mathrm{C}$ & $27.50^{\mathrm{d}}$ & $25.00^{\mathrm{d}}$ & $30.50^{\mathrm{d}}$ & $27.66^{\mathrm{c}}$ & $14.50^{\mathrm{c}}$ & $12.50^{\mathrm{c}}$ & $24.50^{\mathrm{c}}$ & $17.16^{\mathrm{c}}$ \\
\hline S & $3.75^{\mathrm{a}}$ & $7.50^{\mathrm{a}}$ & $15.75^{\mathrm{a}}$ & $9.00^{\mathrm{a}}$ & $5.00^{\mathrm{a}}$ & $6.25^{\mathrm{a}}$ & $13.75^{\mathrm{a}}$ & $8.33^{\mathrm{a}}$ \\
\hline $\mathrm{BC}$ & $12.50^{\mathrm{c}}$ & $8.75^{\mathrm{ab}}$ & $19.00^{\mathrm{bc}}$ & $13.41^{\mathrm{b}}$ & $10.00^{\mathrm{b}}$ & $7.25^{\mathrm{a}}$ & $17.00^{\mathrm{b}}$ & $11.41^{\mathrm{b}}$ \\
\hline $\mathrm{BP}$ & $7.50^{\mathrm{ab}}$ & $16.25^{\mathrm{c}}$ & $20.75^{\mathrm{c}}$ & $14.83^{\mathrm{b}}$ & $8.00^{\mathrm{b}}$ & $12.25^{\mathrm{c}}$ & $18.50^{\mathrm{b}}$ & $12.91^{b}$ \\
\hline $\mathrm{T}$ & $10.00^{\mathrm{bc}}$ & $11.25^{\mathrm{b}}$ & $18.25^{\mathrm{b}}$ & $13.16^{\mathrm{b}}$ & $9.00^{\mathrm{b}}$ & $9.75^{\mathrm{b}}$ & $17.25^{\mathrm{b}}$ & $12.00^{\mathrm{b}}$ \\
\hline Mean & 12.25 & 13.75 & 20.85 & & 9.30 & 9.60 & 18.20 & \\
\hline
\end{tabular}

C: control; S: Switch 62.5 WG; BC: beta-chikol; BP: Boni protect forte; T: Trianum P.

a-d Values designated with the same letters do not significantly differ in columns $(P \leq 0.05$; Tukey's test $)$. 
Table 2 Fungi colonizing strawberry plant cv. "Elsanta” protected by biological preparations in 2012.

\begin{tabular}{|c|c|c|c|c|c|c|c|c|c|c|c|c|c|c|c|c|}
\hline \multirow{3}{*}{ Fungus species } & \multicolumn{15}{|c|}{ Experimental combination } & \multirow{3}{*}{ Total } \\
\hline & \multicolumn{3}{|c|}{$\mathrm{C}$} & \multicolumn{3}{|c|}{$\mathrm{BC}$} & \multicolumn{3}{|c|}{$\mathrm{BP}$} & \multicolumn{3}{|c|}{$\mathrm{T}$} & \multicolumn{3}{|c|}{$\mathrm{S}$} & \\
\hline & 1 & $\mathrm{c}$ & $\mathrm{r}$ & 1 & c & $\mathrm{r}$ & 1 & $\mathrm{c}$ & $\mathrm{r}$ & 1 & $\mathrm{c}$ & $\mathrm{r}$ & 1 & $\mathrm{c}$ & $\mathrm{r}$ & \\
\hline Alternaria alternata (Fr.) Keissler & 78 & & 12 & 62 & 6 & 11 & 72 & 1 & 1 & 34 & & & 58 & 2 & 1 & 338 \\
\hline Aspergillus flavus Link & & & & & & & & & & & & 1 & & 1 & & 2 \\
\hline Botrytis cinerea Pers. & & & 7 & 6 & & & & & & 1 & & & 2 & & & 16 \\
\hline Chaetomium funicola Cooke & & & & & & & & & & & & & & & 67 & 67 \\
\hline Cylindrocarpon destructans (Zins.) Scholten & & 2 & & & & & & & & & & & & & & 2 \\
\hline Cylindrocarpon didymum (Hartig) Wollenw. & & & 45 & & & & & 10 & & & & 64 & & & & 119 \\
\hline Fusarium avenaceum (Fr.) Sacc. & 101 & 4 & 17 & 49 & 20 & 81 & 14 & & 85 & 1 & & & 8 & 6 & 10 & 396 \\
\hline Fusarium equiseti (Corda) Sacc. & & & & & 2 & & 2 & 2 & & 2 & & & & 14 & 6 & 28 \\
\hline Fusarium oxysporum Schl. & 2 & 7 & 7 & 11 & 30 & 19 & 1 & & 19 & & 20 & 14 & 5 & & 13 & 148 \\
\hline Fusarium poae (Peck) Wollenw. & & & & & & & & & & 5 & & & & & & 5 \\
\hline Fusarium sporotrichioides Scherb. & & & & & & & 11 & 2 & & 40 & 8 & 13 & 36 & 12 & & 122 \\
\hline Fusarium solani (Mart.) Sacc. & & 5 & & & 2 & 1 & & & & & & 1 & & & & 9 \\
\hline Gliocladium fimbriatum Gilman et Abbott & & & & & & & & 41 & & & & & & 29 & & 70 \\
\hline Leptothyrium fragariae Lorr. et Sm. & & 2 & & & & & & 1 & & & & & & & & 3 \\
\hline Penicillium purpurogenum Stoll & 6 & 21 & & & & & & & & & & & & & & 27 \\
\hline Pestalotia trunctata Lev. & & 1 & & & 3 & 1 & 1 & & & & & & & & & 6 \\
\hline Phoma exigua Desm. & & 1 & & & & & & & & & & & & & & 1 \\
\hline Phomopsis obscurans (Ell. \& Ev.) Sutton & & & & & & & & & & 2 & & & & & & 2 \\
\hline Rhizoctonia solani Kühn & & & & 27 & 4 & 6 & 14 & 3 & 22 & & & & & & 2 & 78 \\
\hline Trichoderma harzianum Rifai & & & & & & & & & & & 69 & 38 & & & & 107 \\
\hline Total & 187 & 43 & 88 & 155 & 67 & 119 & 115 & 60 & 127 & 85 & 97 & 131 & 109 & 64 & 99 & 1,546 \\
\hline
\end{tabular}

1: leaf; c: crown; r: root.

Table 3 Fungi colonizing strawberry plant cv. "Elsanta” protected by biological preparations in 2013.

\begin{tabular}{|c|c|c|c|c|c|c|c|c|c|c|c|c|c|c|c|c|}
\hline \multirow{3}{*}{ Fungus species } & \multicolumn{15}{|c|}{ Experimental combination } & \multirow{3}{*}{ Total } \\
\hline & \multicolumn{3}{|c|}{$\mathrm{C}$} & \multicolumn{3}{|c|}{$\mathrm{BC}$} & \multicolumn{3}{|c|}{$\mathrm{BP}$} & \multicolumn{3}{|c|}{$\mathrm{T}$} & \multicolumn{3}{|c|}{$\mathrm{S}$} & \\
\hline & 1 & c & $\mathrm{r}$ & 1 & $\mathrm{c}$ & $\mathrm{r}$ & 1 & $\mathrm{c}$ & $\mathrm{r}$ & 1 & $\mathrm{c}$ & $\mathrm{r}$ & 1 & c & $\mathrm{r}$ & \\
\hline Alternaria alternata (Fr.) Keissler & 8 & & 1 & 6 & & & 7 & & & 6 & & & & & & 28 \\
\hline Botrytis cinerea Pers. & 33 & 10 & & 50 & 30 & 6 & 13 & 2 & & 51 & 3 & 3 & 4 & 2 & & 207 \\
\hline Cylindrocarpon destructans (Zins.) Scholten & & & 9 & & 3 & & & & & & & & & & & 12 \\
\hline Cylindrocarpon didymum (Hartig) Wollenw. & & & & & & & & & & & & 31 & & 6 & & 37 \\
\hline Fusarium avenaceum (Fr.) Sacc. & 7 & 18 & 2 & & 4 & 33 & 41 & 18 & 2 & 1 & 8 & 18 & 15 & 3 & 4 & 174 \\
\hline Fusarium equiseti (Corda) Sacc. & & & & & & & & 11 & & & & & 1 & 1 & 59 & 72 \\
\hline Fusarium oxysporum Schl. & & & 11 & & 1 & 7 & & & 16 & & 1 & 39 & 2 & & 26 & 103 \\
\hline Fusarium sporotrichioides Scherb. & & & & & & & & & & & & & 39 & & & 39 \\
\hline Gliocladium fimbriatum Gilman et Abbott & 6 & 2 & 47 & 1 & 7 & 8 & 11 & 10 & 44 & & & & & & & 136 \\
\hline Leptothyrium fragariae Lorr. et Sm. & 1 & & & & & & & & & & & & & & & 1 \\
\hline Penicillium purpurogenum Stoll & & 8 & & & 8 & & & 4 & & 19 & & & & & & 39 \\
\hline Pestalotia trunctata Lev. & 1 & & & 2 & & & & & & & & & & 2 & & 5 \\
\hline Phoma exigua Desm. & 5 & & & 1 & & 3 & & & & & & & & & & 9 \\
\hline Rhizoctonia solani Kühn & & & 24 & & & 5 & & & & & & 6 & & & & 35 \\
\hline Trichoderma harzianum Rifai & & & & & & & & & & & 8 & & & & & 8 \\
\hline Total & 61 & 38 & 94 & 60 & 53 & 62 & 72 & 45 & 62 & 77 & 20 & 97 & 61 & 14 & 89 & 905 \\
\hline
\end{tabular}


Table 4 Fungi colonizing strawberry plant cv. "Elsanta" protected by biological preparations in 2014.

\begin{tabular}{|c|c|c|c|c|c|c|c|c|c|c|c|c|c|c|c|c|}
\hline \multirow{3}{*}{ Fungus species } & \multicolumn{15}{|c|}{ Experimental combination } & \multirow{3}{*}{ Total } \\
\hline & \multicolumn{3}{|c|}{$\mathrm{C}$} & \multicolumn{3}{|c|}{$\mathrm{BC}$} & \multicolumn{3}{|c|}{$\mathrm{BP}$} & \multicolumn{3}{|c|}{$\mathrm{T}$} & \multicolumn{3}{|c|}{$\mathrm{S}$} & \\
\hline & 1 & $\mathrm{c}$ & $\mathrm{r}$ & 1 & $\mathrm{c}$ & $\mathrm{r}$ & 1 & $\mathrm{c}$ & $\mathrm{r}$ & 1 & $\mathrm{c}$ & $\mathrm{r}$ & 1 & $\mathrm{c}$ & $\mathrm{r}$ & \\
\hline Alternaria alternata (Fr.) Keissler & & 1 & & & 1 & 5 & & & & & & & 2 & & & 9 \\
\hline Aureobasidium pullulans (De Bary) Arnoud. & & & & & & & & & & & & & 1 & & & 1 \\
\hline Botrytis cinerea Pers. & 77 & 1 & & 67 & 14 & 1 & 68 & 1 & 8 & 69 & 4 & 3 & 53 & 10 & 3 & 379 \\
\hline Cladosporium cladosporioides (Fres.) de Vries & & & & & & & & & & 8 & & 3 & & & & 11 \\
\hline Colletotrichum acutatum Simmonds & & & & & & & & 5 & & & 8 & & 4 & 1 & & 18 \\
\hline Cylindrocarpon destructans (Zins.) Scholten & & & & & & & & & & & 27 & & & 11 & & 38 \\
\hline Cylindrocarpon didymum (Hartig) Wollenw. & & & & & & & & & & & & 1 & & & & 1 \\
\hline Cylindrocarpon obtusisporum Wellen & & & & & & & & & 8 & & & & & & & 8 \\
\hline Fusarium avenaceum (Fr.) Sacc. & & 20 & 70 & & 21 & 46 & & 7 & 6 & & 9 & & & 6 & 2 & 187 \\
\hline Fusarium culmorum (Smith) Sacc. & & & 10 & & 2 & & & 3 & & & & 20 & & & & 35 \\
\hline Fusarium oxysporum Schl. & & 4 & 4 & & 4 & 21 & & 17 & 8 & & 5 & 9 & & 4 & 45 & 121 \\
\hline Fusarium sporotrichioides Scherb. & & 9 & & & 1 & 2 & & 11 & & & & & & & & 23 \\
\hline Gliocladium fimbriatum Gilman et Abbott & & & & & 1 & & 1 & & & & & & & 2 & 3 & 7 \\
\hline Leptothyrium fragariae Lorr. et Sm. & & & & & & & & & & 1 & & & & & & 1 \\
\hline Penicillium purpurogenum Stoll & & & & & & & & 7 & & & & & & 10 & & 17 \\
\hline Phomopsis obscurans (Ell. \& Ev.) Sutton & & & & & & & & & & 1 & & & 1 & & & 2 \\
\hline Rhizoctonia solani Kühn & & & & & & & & 31 & 69 & & & 7 & & 15 & 24 & 146 \\
\hline Trichoderma harzianum Rifai & & & & & & & & & & & 19 & & & & & 19 \\
\hline Total & 77 & 35 & 84 & 67 & 44 & 75 & 69 & 82 & 99 & 79 & 72 & 43 & 61 & 59 & 77 & 1,023 \\
\hline
\end{tabular}

not only inhibits the growth of many fungi, but also induces chitinase activity, and elicits phytoalexins and defense barriers in the host tissues [24-27]. The compound can also produce a moisture barrier and delay the senescence process of plants which increase the resistance of plants to fungal infection [14]. Other researchers noticed that chitosan can act directly at pathogenic fungi, damaging the spores and the mycelium [28].

Boni protect forte and Trianum $\mathrm{P}$ showed the similar efficacy in the protection of strawberry. Aureobasidium pullulans, an active agent of Boni protect forte, is a yeast-like fungus colonizing the plants under natural conditions [29]. The development of Aureobasidium pullulans depends on many factors, such as the temperature, $\mathrm{pH}$ and the content of nutrients in the substrate. The efficacy of the fungus was reported by many authors [30-34]. The effectiveness of the antagonist may be attributed to nutrient competition, competition for space, direct parasitism, production of enzymes and induced resistance [35]. The fungus produces many compounds biologically active, like enzymes, antibiotics, polysaccharides and single cell proteins. An important polysaccharide produced by Aureobasidium pullulans is pullulan, which causes the degradation of plant call walls [36]. The observed reduction of disease severity in studied strawberry plants may be the result of its complicated action. The successful competition of the fungus for nutrients and space can make pathogen cells weak, and can increase pathogen susceptibility to host enzymes and possibly to antibiotic compounds produced by the antagonist [37].

Trichoderma harzianum, an active component of Trianum $\mathrm{P}$, is for many years widely known as an effective antagonist. Its mode of action includes the mycoparasitism, the antibiosis and the competition as well as the stimulation of plant defense mechanisms [38]. The biopreparations based on Trichoderma spp. are effective in the control of many fruit and vegetable crops [39-42]. The production of antibiotic by Trichoderma spp. is well documented. Among others, gliotoxin, viriden, peptaboils, sesquiterpenens and 
isonitryles belong to toxic enzymes [43]. Trichoderma spp. also can parasite many pathogenic fungi $[38,39]$ through the degradation of pathogen cell walls with chitinolytic enzymes [44-46]. The positive effect of Trianum $\mathrm{P}$ was shown also in the lower number of pathogens isolates obtained from the plants grown in this combination. In 2012 and 2014, the numbers of potentially pathogenic isolates in the combination with Trianon $\mathrm{P}$ were lower by $75 \%$ and $20 \%$, respectively, than that in the control combination. Only in 2013, the number of pathogens colonies was similar. However, every year from the plants grown in this combination, the isolates of Trichoderma harzianum were obtained, which may suggest the possibility of antagonistic action of the fungus against the pathogens.

The results of mycological analysis are not as convincing as the evaluation of health status of strawberry plants. However, it should be remembered that not all the isolates in the populations of potentially pathogenic fungi should be pathogenic to any host. Some of them might be only non-pathogenic colonizers [47]. According to the results in this study, the tested bioproducts can be used for the production of strawberry, especially in organic farms.

\section{Conclusions}

In conclusion, this study showed that all tested biological preparations had a potential in the biological control of strawberry diseases. The health status of strawberry plants treated with the tested bioproducts and the fungicide was significantly better than the health status of untreated plants. The percentage of diseased plants and the disease index were significantly lower for the treated plants comparing to untreated plants. There were no significant differences in mean percentage of plants with symptoms and disease index between the combinations with tested bioproducts. It is difficult to interpret the effect of the preparations on the fungal populations isolated from strawberry plants, however, in the combination with Trianum $\mathrm{P}$, the number of potentially pathogenic isolates was the lowest. Further experiments would still be required to confirm the efficacy of these products in the control of the most important pathogens of strawberry.

\section{Acknowledgments}

The authors are grateful to the National Science Center in Poland for financial support in the form of Grant No. N310 771640.

\section{References}

[1] Labanowska, B. H., Meszka, B., Bielenin, A., and Olszak, R. 2004. "A Field Evaluation of Disease and Insect Resistance of Several Strawberry Cultivars in Poland." Acta Hort. 649: 255-8.

[2] Wagner, A., and Hetman, B. 2016. "Susceptibility of Some Strawberry Cultivars to Colletotrichum acutatum J. H. Simmons." Acta Sci. Pol. Hortorum Cultus 15 (6): 209-19.

[3] Hahn, M. 2014. "The Rising Threat of Fungicide Resistance in Plant Pathogenic Fungi: Botrytis as a Case Study." J. Chem. Biol. 7 (4): 133-41.

[4] Maleshko, N. 2005. "The Possibility of Using the Biological Preparations against Grey Mold of Strawberry (Botrytis cinerea Pers.).” Prog. Plant Prot. 45: 236-40. (in Polish)

[5] Shoarma, R. R., Singh, D., and Singh, R. 2009. "Biological Control of Postharvest Diseases of Fruits and Vegetables by Microbial Antagonists: A Review." Biol. Control 50 (3): 205-21.

[6] Jamiołkowska, A., and Wagner, A. 2011. "Effect of Garlic Pulp (Bioczos Plynny) on Some Fungi Pathogenic to Vegetables." In Proceedings of French Association of Plant Protection (AFPP) Fourth International Conference on Non-chemical Crop Protection Methods, 213-20.

[7] Kowalska, J. 2011. "Effects of Trichoderma asperellum (T1) on Botrytis cinerea (Pers.:Fr.), Growth and Yield of Organic Strawberry." Acta Sci. Pol. Hortorum Cultus 10 (4): 107-14.

[8] Freeman, S., Minz, D., Kolesnik, I., Barbul, O., Zveibil, A., and Maymon, M. 2004. "Trichoderma Biocontrol of Colletotrichum acutatum and Botrytis cinerea and Survival in Strawberry." Europ. J. Plant Path. 110 (4): 361-70.

[9] Kordowska-Wiater, M., Wagner, A., and Hetman, B. 2012. "Efficacy of Candida melibiosica for Control of Postharvest Diseases of Carrot (Daucus carota L.)." Acta 
Sci. Pol. Hortorum Cultus 11 (5): 55-65.

[10] Janisiewicz, W., Saftner, R., Conway, W., and Yoder, K. 2008. "Control of Blue Mold Decay of Apple during Commercial Controlled Atmosphere with Yeasts Antagonists and Sodium Bicarbonate." Postharvest Bio. Technol. 49 (3): 374-8.

[11] Jamiolkowska, A. 2009. "The Influence of Biopreparation Biosept 33 SL on Fungi Colonizing Sweet Pepper Plants (Capsicum annuum L.) Cultivated in the Field." EJPAU 12 (3). Accessed August 2009. http://www.ejpau.media.pl/volume12/issue3/art-13.html.

[12] Saniewska, A., and Zurawska, I. 2001. "Comparison of Antifungal Activity of Four Cultivars of Garlic (Allium sativum L.) for Several Pathogenic Fungi." Folia Hort. 13: 405-12.

[13] Romanozzi, G., Feliziani, E., Santini, M., and Landi, L. 2013. "Effectiveness of Postharvest Treatment with Chitosan and Other Resistance Inducers in the Control of Storage Decay of Strawberry." Postharvest Biol. Technol. 75: 24-7.

[14] Reddy, M. V. B., Belkacemi, K., Corcuff, R., Castaigne, F., and Arul, J. 2000. "Effect of Preharvest Chitozan Sprays on Postharvest Infection by Botrytis cinerea and Quality of Strawberry Fruit." Postharvest Biol. Technol. 20 (1): 39-51.

[15] Ippolito, A., El-Ghaouth, A., Wilson, C. L., and Wisniewski, M. 2000. "Control of Postharvest Decay of Apple Fruit by Aureobasidium pullulans and Induction of Defense Responses.” Postharvest Biol. Technol. 19 (3): 265-72.

[16] Kopacki, M., and Wagner, A. 2004. "Pathogenicity of Fusarium spp. to Chrysanthemum (Dendranthema grandiflora Tzvelev)." Latvian Journal of Agronomy 7: 158-60.

[17] Orlikowski, L. B., and Skrzypczak, C. 2003. "Biocides in the Control of Soil-Borne and Leaf Pathogens." Hortic. Veget. Grow. 22 (3): 426-33.

[18] Pięta, D., Patkowska, E., and Pastucha, A. 2005. "The Protective Effect of Biopreparations Applied as Dressing for Common Bean (Phaseolus vulgaris L.) and Pea (Pisum sativum L.)." Acta Sci. Pol.-Hortorum Cultus 4 (2): 59-67.

[19] Arunkmar, K., Sivakumar, S. R., and Rengasamy, R. 2010. "Review on Bioactive Potential in Seaweeds (Marine Macroalgae): A Special Emphasis on Bioactivity of Seaweeds against Plant Pathogens." Asian J. Plant Sci. 9 (5): 227-40.

[20] Sultana, V., Baloch, G. N., Ara, J., Esteshamul-Haque, S., Tariq, R. M., and Athar, M. 2011. "Seaweeds as Alternative to Chemical Pesticides for the Management of Root Diseases of Sunflower and Tomato." J. Appl. Bot. Food Quality 84 (2): 162-8.
[21] El-Ghaouth, A., Arul, J., Grenier, J., and Asselin, A. 1991. "Glucanohydrolases and Inhibitory Activity of Botrytis cinerea in Extracts of Strawberry Fruits." Canadian J. Plant Pathol. 13: 315-20.

[22] El-Ghaouth, A., Arul, J., Pannampolem, R., and Boulet, M. 1991. "Chitosan Coating Effect on Storability and Quality of Fresh Strawberries." J. Food Sci. 56 (6): 1618-20.

[23] Davis, D. H., and Elson, C. M. 1994. "N,O-Carboxymethyl Chitosan: A Preservative Coating for Fruits and a Sonar Transducer Fluid." Presented at the Asia-Pacific Chitin and Chitosan Symposium (APCCS), May 24-27, 1994, Universiti Kebaugsaan Malaysia, Bargi, Malaysia.

[24] El-Ghaouth, A., Arul, J., Wilson, C., and Benhamou, N. 1994. "Ultrastructural and Cytochemical Aspects of the Effect of Chitosan on Decay of Bell Pepper Fruit." Physiol. Mol. Plant Pathol. 44 (6): 417-32.

[25] El-Ghaouth, A., Arul, J., Wilson, C., and Benhamou, N. 1997. "Biochemical and Cytochemical Aspects of the Interaction of Chitosan and Botrytis cinerea in Bell Pepper Fruit." Postharvest Biol. Technol. 12 (2): 183-94.

[26] El-Hadrami, A., Adam, L. R., El-Hadrami, I., and Daayf, F. 2010. "Chitosan in Plant Protection." Mar. Drugs 8 (4): 968-87.

[27] Sun, T., Yao, Q., Zhou, D. X., and Mao, F. 2008. "Antioxidant Activity of N-Carboxymethyl Chitosan Oligosaccharides." Bioorg. Med. Chem. Lett. 18 (21): 5774-6.

[28] Urban, L., Wagner, A., and Struszczyk, H. 2004. "Effect of Treatment with Chitosol 1 on Fusariosis of Tomato." Latvian Journal of Agronomy 7: 153-4.

[29] Mounier, R., Durieux, A., Bodo, C., Allard, C., Simon, J. P., Achbani, E. H., El-Jaafari, S., Douira, A., and Jijakli, M. H. 2007. "Production, Formulation and Antagonistic Activity of Biocontrol Like-Yeast Aureobasidium pullulans against Penicillium expansum." Biotechnol. Lett. 29 (4): 553-9.

[30] Ippolito, A., Nigro, F., Romanazzi, G., and Campanella, V. 1997. "Field Application of Aureobasidium pullulans against Botrytis Storage Rot of Strawberry." In Non-conventional Methods for the Control of Postharvest Disease and Microbiological Spoilage, edited by Bertolini, P., Sijmons, P. C., Guerzoni, M. E., and Serra, F. Bologna, Italy: University of Bologna, 127-33.

[31] Prokkola, S., and Kivijärvi, P. 2007. "Effect of Biological Sprays on the Incidence of Grey Mould, Fruit Yield and Fruit Quality in Organic Strawberry Production.” Agric. Food Sci. 16 (1): 25-33.

[32] Lima, G., Ippolito, A., Nigro, F., and Salerno, M. 1997. "Effectiveness of Aureobasidium pullulans and Candida oleophila against Postharvest Strawberry Rots." 
Postharvest Biol. Technol. 10 (2): 169-78.

[33] Sylla, J., Alsanius, B. W., Krüger, E., Reineke, A., Bischoff-Schefer, M., and Wohanka, W. 2013. "Introduction of Aureobasidium pullulans to the Phyllosphere of Organically Grown of Strawberries with Focus on Its Establishment and Interactions with the Resident Microbiome." Agronomy 3 (4): 704-31.

[34] Wagner, A., Hetman, B., Kopacki, M., Jamiołkowska, A., Krawiec, P., and Lipa, T. 2013. "Laboratory Effect of Boni Protect Containing Aureobasidium pullulans (de Bary) Arnoud in the Control of Some Fungal Diseases of Apple Fruit." Acta Agrobot. 66 (1): 77-88.

[35] Chi, Z. M., Wang, F., Chi, Z., Yue, L., Liu, G., and Zhang, T. 2009. "Bioproducts from Aureobasidium pullulans, a Biotechnology Important Yeast." Appl. Microbiol. Biotechnol. 82 (5): 793-804.

[36] Gaur, R., Singh, R., Gupta, M., and Gaur, M. K. 2010. "Aureobasidium pullulans, an Economically Important Polymorphic Yeast with Special Reference to Pullulans." African J. Biotech. 9 (47): 7989-97.

[37] Adikaram, N. K. B., Joyce, D. C., and Terryc, L. A. 2002. "Biocontrol Activity and Induced Resistance as a Possible Mode of Action for Aureobasidium pullulans against Grey Mould of Strawberry Fruit.” Australasian Plant Pathol. 31 (3): 223-8.

[38] Benitez, T., Rincon, A. M., Limón, M. C., and Codon, A. C. 2004. "Biocontrol Mechanisms of Trichoderma Strains.” Int. Microbial. 7 (4): 249-60.

[39] Larkin, R. P. 2016. "Impact of Biocontrol Products on Rhizoctonia Disease of Potato and Soil Microbial Communities and Their Persistence in Soil." Crop Prot. 90: 96-105.

[40] Pascale, A., Vinale, F., Manganiello, C., Nigro, M.,
Lanzuise, S., Ruocco, M., Marraa, R., Lombardia, N., Wooa, S. L., and Loritoa, M. 2017. "Trichoderma and Its Secondary Metabolites Improve Yield and Quality of Grapes." Crop Prot. 92: 176-81.

[41] Lifschitz, R., Lifshitz, S., and Baker, R. 1985. "Decrease in Incidence of Rhizoctonia Pre-emergence Damping-Off by Use of Integrated Chemical and Biological Controls." Plant Dis. 69 (5): 431-4.

[42] Elad, Y. 2000. "Trichoderma harzianum T39 Preparation for Biocontrol of Plant Disease-Control of Botrytis cinerea, Sclerotinia sclerotiorum and Cladosporium fulvum." Biocontrol Sci. Technol. 10 (4): 499-507.

[43] Beng, A., Wangum, H. V., Nkengfack, A. E., and Schlegel, B. 2004. "Lignoren, a New Sesquiterpenoid Metabolite fron Trichoderma lignorum HKI 0257." J. Basic Microbiol. 44 (4): 317-9.

[44] El-Katany, M. H., Somitsch, W., Robra, K. H., El-Katany, M. S., and Gubitz, G. M. 2000. "Production of Chitinase and $\beta-1,3-G l u c o n a s e$ by Trichoderma harzianum for Control the Phytopathogenic Fungus Sclerotium rolfsii." Food Technol. Biotechnol. 38 (3): 173-80.

[45] Kubicek, C. P., Mach, R. L., Peterbauer, C. K., and Lorito, M. 2001. "Trichoderma: from Genes to Biocontrol.” J. Plant Path. 83: 11-23.

[46] Ozbay, N., and Newman, S. E. 2004. "Biological Control with Trichoderma spp. with Emphasis on T. harzianum." Pakistan J. Biological Sci. 7 (4): 478-84.

[47] Wagner, A., Jamiołkowska, A., and Michałek, W. 2007. "Pathogenicity of Fusarium oxysporum from Different Soil Environments and Its Effect on Phytosynthetic Activity of Tomato Plants." EJPAU 10 (1). Accessed January $16, \quad 2007$. http://www.ejpau.media.pl/volume10/issue1/art-29.html. 